\title{
Legisprudential Evaluation of Ethiopian Criminal Law-Making
}

Simeneh Kiros Assefa *

\begin{abstract}
The state adopts criminal rules and punishment in order to achieve various state ends. There is very little agreement regarding the content of 'good criminal law'. However, there is a general agreement regarding 'good' criminal lawmaking process. This article argues that the lawmaking process may be used to evaluate the legitimacy of the criminalisation process. Thus, it discusses prelegislation, legislation and post-legislation phase duties of the legislature and finds that these processes were not complied with in various Ethiopian laws that contain penal provisions.
\end{abstract}

\section{Key terms:}

Legisprudence $\cdot$ Criminal law $\cdot$ Criminal lawmaking $\cdot$ Law and politics $\cdot$

Legislation rules

DOI http://dx.doi.org/10.4314/mlr.v14i2.1

This article is licensed under a Creative Commons Attribution-

NonCommercial-NoDerivs (CC BY-NC-ND)

Received: 3 July 2020

Accepted: 19 December 2020

\section{Suggested citation:}

Simeneh Kiros Assefa (2020), 'Legisprudential Evaluation of Ethiopian

Criminal Lawmaking’, 14 Mizan Law Review 2: 161-200

\section{Introduction}

The state has various means at its disposal to achieve its social, economic and political objectives. Legislative intervention is one of the instruments of last resort to achieve these ends. This power is expected to be exercised in a manner that reduces or avoids undue discretion and arbitrary acts that disregard legitimate, rational and proper procedural law-making processes and substantive content. Thus, in as much as the legislature has the authority to make law, it also has the duty in making the law -to make laws that are

- Simeneh Kiros Assefa, PhD, Associate Professor of Law, Addis Ababa University School of Law; Email: simeneh@simenehlaw.com ORCID: https://orcid.org/0000-0003-0915-9360 
not only formally valid but also coherent and that make sense in the real world. ${ }^{l}$ At the pre-legislative stage, the legislature investigates the social circumstances requiring legislative intervention. Because the criminal law implicates fundamental rights, the lawmaker first evaluates the available alternative measures, and it chooses the least intrusive method. The lawmaker also makes legislative impact assessment taking the existing and future circumstances into account.

To make an efficacious law, the lawmaker deliberates both in Committees and in the House; and the decision is made based on the available data. The initial stage of the validity of a norm relates to its formal validity; continuous validity of such norm may be maintained if the norm maintains its goal rationality. A norm may be invalid through time or as new realities and further information emerge. Therefore, continuous evaluation of such a norm is the post-legislation duty of the lawmaker. If there is such continuous assessment of the legislation, resort to judicial review would be less attractive because the court would defer to the decision of the lawmaker.

This article examines whether such legisprudential requirements set out in the law were met in making the various criminal rules. It examines lawmaking rules, draft bills containing penal provisions and the respective explanatory memoranda, minutes of Committee hearings, reports and recommendations of the respective Committees and the final legislation containing penal rule. After such examination, it finds that those legislation containing penal provisions and reviewed in this study do not meet several of the legislation requirements set out in the law.

The first section highlights the rules of lawmaking and the lawmaking process that is governed by law so that the lawmaker can make rational laws. Section 2 briefly discusses the relation between law and politics that can vary depending on the theory of law one adopts. Section 3 highlights

1 Luc J Wintgens (2002), 'Legislation as an Object of Study of Legal Theory: Legisprudence' in Luc J Wintgens (ed), Legisprudence: A New Theoretical Approach to Legislation (Hart Publishing) $26 \mathrm{ff}$; Luc J Wintgens, 'The Rational Legislation Revisited: Bounded Rationality and Legisprudence' in Luc J Wintgens and A Daniel Oliver-Lalana (eds), The Rationality and Justification of Legislation (Springer 2013) at 3, 5 ff; Luc J Wintgens 'Legisprudence as a New Theory of Legislation' in Luc J Wintgens, The Theory and Practice of Legislation: Essays in Legisprudence (Routledge 2005) at 18-22; Robert Alexy (2002, The Argument from Injustice: A Reply to Legal Positivism (Bonnie L Paulson and Stanley L Paulson tr, Clarendon Press) at 85-88; Hans Kelsen, Pure Theory of Law (Max Knight tr, The Lawbook Exchange, 2005) at 211-214. Also see Lon L Fuller (1969), The Morality of Law (revised edn, Yale UP). 
criminal lawmaking power and the federal legislation. Section 4 discusses pre-legislation matters, such as bill initiation and pre-legislation deliberations, the core responsibilities of the lawmaker including the obligation to investigate into the facts of the failed social interaction or other factors that necessitate legislation. Sections 5 to 7 address issues relating to the gaps in the background study of various specific criminal legislation, the need for legislative impact assessment (including proactive projections relating to outcomes and impact), and the duty to maintain coherence of the law both internally and externally. Section 8 highlights the duty to deliberate and to give reason, and Section 9 deals with the post-legislation duty of the lawmaker relating to continuous evaluation.

\section{General Background}

The principal duties of the legislature is enacting laws and supervising the executive to ensure that the laws are properly implemented. ${ }^{2}$ The three core functions of the legislature, i.e. representation, lawmaking and oversight are inter-related. In enacting laws, the lawmaker is bound by legislation rules, such as The Federal Democratic Republic of Ethiopia Constitution Proclamation No 1/1995 ('FDRE Constitution') and its lawmaking rules. The Constitution provides for a formal and material source of legislative power. ${ }^{3}$ As such, the federal lawmaker makes laws on matters that are reserved for the Federal Government and it is specifically authorised to adopt 'a penal code'.

The current rules of lawmaking are the Federal Democratic Republic of Ethiopia House of Peoples' Representatives Working Procedure and Members' Code of Conduct (Amendment) Proclamation No 470/2005, ${ }^{4}$ The House of Peoples' Representatives Rules of Procedure and Members' Code

\footnotetext{
${ }^{2}$ Federal Democratic Republic of Ethiopia House of Peoples' Representatives Working Procedure and Members' Code of Conduct (Amendment) Proclamation No 470/2005, arts 4(1), (2), 6, 7, 19(1), (2); House of Peoples' Representatives Rules of Procedure and Members' Code of Conduct Regulations No 6/2015, arts 3, $49 \mathrm{ff}, 73 \mathrm{ff}$.

3 For instance, the provisions of The Federal Democratic Republic of Ethiopia Constitution Proclamation No 1/1995 ('FDRE Const'), art 51 provide for the powers reserved for the Federal Government while art 55 provides for areas of legislation for the HoPR.

4 The word 'amendment' in the title of the statute gives the impression that there are other already existing rules that are still in force; but that is not the case. The House of Peoples' Representatives Legislative Procedure, Committees Structure, and Working Proclamation No 271/2002 is repealed. Proc No 470/2005, supra note 2, art 40(1).
} 
of Conduct Regulations No 6/2015. The other and most important rule is the Council of Ministers Working Directive 1996 EC (in Amharic, 'CM Working Directive') governing policy and bill initiation and adoption procedure in the Council of Ministers. A Legislative Drafting Manual was also drafted in late $2010 \mathrm{EC}^{5}$

Complying with the requirements of these rules is the internal view of the legislature. Some have reservations about the legalistic view of such law. ${ }^{6}$ As is evident from the readings of those rules and the working of the lawmaker, the latter is adopting laws not for the law's good but as a means to achieve certain social, economic and political ends. ${ }^{7}$ Because the lawmaking process is also guided by the principles in other disciplines the law is meant to address, those principles are used for the evaluation of the substantive validity of the $\operatorname{law}^{8}$ which constitute 'hermeneutic view of the legislature'. ${ }^{9}$

The nature of the lawmaking process defines the content of the outcome legislation. Even though there could not be disagreement that the lawmaker should adopt 'good law', the content of such 'good law' is a point where there is very little ideological and theory-neutral agreement. Thus, the procedure helps the lawmaker to come up with a reasonably agreeable result. ${ }^{10}$ Those processes also include taking into account important interests in a fair and participatory manner. The process fairly guarantees the quality of the outcome.

A. Daniel Oliver-Lalana argues that it is possible to make good normative judgments only after a proper debate, and this argument is based on five assumptions: (i) Collective normative decisions require 'good reason' which could emerge only from an argumentation process; (ii) As legitimacy grows slowly, rational lawmaking is impossible without argumentation; (iii) There is a strong connection between the quality of law and its reasons; (iv) The perspectives of those who participate may be incorporated through argumentation; and (v) The deliberations give us a vantage point of the

${ }^{5}$ Draft Legislative Drafting Manual 2010 EC (in Amharic).

${ }^{6}$ Wintgens 'Legislation as an Object of Study' supra note 1, at $18 \mathrm{ff}$.

${ }^{7}$ See the national policy principles and objectives in FDRE Const, arts 85 - 92. 'Brief Explanatory Memorandum to the Draft Constitution Certified by Council of Representatives 28 October 1994' (in Amharic) at 123 - 24.

${ }^{8}$ Wintgens 'Legislation as an Object of Study' supra note 1, 31.

${ }^{9}$ Id., at $29 \mathrm{ff}$.

10 Jeremy Waldron (2006), 'Principles of Legislation' in Richard W Bauman and Tsvi Kahana (eds), The Least Examined Branch: The Role of Legislatures in the Constitution State (Cambridge UP). 
justifications of the legislation. ${ }^{11}$ However, the process needs to be complied with for its own sake, which Robert Summers refers to as 'process value'. ${ }^{12}$ This is rather what may be referred to as the 'good law' making process. ${ }^{13}$

\section{The Law and Politics Nexus}

The practice of lawyers and the study of legal theorists very much takes on the positive law as a paradigm. ${ }^{14}$ This engendered a 'strong legalism' view of the law. ${ }^{15}$ The positivist distinction between law and non-legal matters appears to have dominated the internal view of lawyers which hold up for such tight distinction between the two disciplines. Some even consign criminalisation to the realm of politics as 'not subject to a rational discussion'. ${ }^{16}$

However, the two disciplines are not as separate as they appear to be. Mauro Zamboni opines that politics is the social element and law is the technical element. ${ }^{17}$ Even Kelsen holds that power and law are two sides of a coin. ${ }^{18}$ The institutional thought of positivism sees the law as an instrument

11 A Daniel Oliver-Lalana 'Rational Lawmaking and Legislative Reasoning in Parliamentary Debates' in Luc J Wintgens and A Daniel Oliver-Lalana (eds), The Rationality and Justification of Legislation (Springer 2013) at 136 - 38.

${ }^{12}$ See generally, Robert S Summers (1974), 'Evaluating and Improving Legal Process: A Plea for Process-Value' 60 Cornell LR 1; Robert S Summers (2006), Form and Function in a Legal System: A General Study (Cambridge UP) at 31, 45, 66- -72, 116$118,124 \mathrm{ff}$.

${ }^{13}$ Wintgens 'Legisprudence as a New Theory' supra note 1, at 22.

${ }^{14}$ Wintgens 'Legislation as an Object of Study' supra note 1, at 14.

15 Ibid 19-24; Wintgens 'Legisprudence as a New Theory' supra note 1, at 5-9; Mauro Zamboni (2008), Law and Politics: A Dilemma for Contemporary Legal Theory (Springer). Also see Alicja Ornowska (2010), 'Introducing Hermeneutic Methods in Criminal Law Interpretation in Europe' in Joanna Jemielniak and Prezmyslaw Miklaszewicz (eds), Interpretation of Law in the Global World: From Particularism to a Universal Approach (Springer) at 257-271.

${ }^{16}$ Nina Persak (2007), Criminalising Harmful Conduct: The Harm Principle, Its Limits and Continental Counterparts (Springer) at 5, 23; Luc J Wintgens (2002), 'Rationality in Legislation - Legal Theory as Legisprudence: An Introduction' in Luc J Wintgens (ed), Legisprudence: A New Theoretical Approach to Legislation (Hart Publishing) at 2; Wintgens 'Legislation as an Object of Study' supra note 1, 30; Oliver-Lalana supra note 11, at 135, 138, 139; Wintgens 'Legisprudence as a New Theory' supra note 1 , at $6-7$.

${ }^{17}$ Zamboni, supra note $15,1$.

18 Kelsen, Pure Theory of Law, supra note 1, at 284-290; La Torre describes the relationship between law and power (state) as the relation between 'chicken-and-egg'. 
which shows a significant overlap between law and politics. ${ }^{19}$ Zamboni examines such relation on three levels, and depending on the degree of the relationship, he developed three models.

The static aspect is 'the law in relation to politics ${ }^{20}$ while the dynamic aspect is 'how the lawmaking relates to the political order'. ${ }^{21}$ The third is the epistemological aspect, 'the degree of the relation of legal discipline to the political material'. ${ }^{22}$ Zamboni observed that the legal theorists' argument range from the politicisation of law, where the state uses the law as part of the 'political machinery'23 to the specialisation of law, where using principles and legal doctrines, such as the principle of legality and the rule of law, the law puts a limit to the power of the state. ${ }^{24}$ Within this range, he identified three models of the relationship between the two disciplines. The autonomous model, which includes such schools as positivism, makes a clear distinction between law and politics at all three levels. ${ }^{25}$ The embedded model, which includes schools, such as law and economics, and critical legal studies, considers the 'law is embedded in politics'. ${ }^{26}$ The third model, the intersection model, including the realist school, considers 'law and politics are intersecting phenomena' ${ }^{27}$

The general observation is that there is a strong relationship between law and politics. It is stating the obvious that the law can never be as 'pure' as traditional positivists would want it to be. It is influenced by other disciplines, such as economics and sociology, and the law is meant to address those social and economic issues. ${ }^{28}$ From this perspective, law is an instrument to achieve those ends. In certain instances, even judges take

Massimo La Torre (2010), Law as Institution (Springer) at 4.

${ }^{19}$ La Torre, supra note 18 , at 3-7, 159-165.

${ }^{20}$ Zamboni, supra note 15, at 1, 7-8.

${ }^{21}$ Id., at 2, $7-8$; Kelsen, Pure Theory of Law, supra note 1, at 193-205.

${ }^{22}$ Zamboni, supra note 15 , at 2, 7-8.

${ }^{23}$ Id., at 3, 7.

${ }^{24}$ Ibid.

${ }^{25}$ Id., at 2. Even in terms of interpretation of the law, positivists are guided by the exegetic method. However, in real life, the court is inevitably guided by hermeneutic interpretation. Simeneh Kiros Assefa (2017), 'Methods and Manners of Interpretation of Criminal Norms' 11 Mizan LR 88, 111. Also see Ornowska, supra note 15; Wintgens 'Legisprudence as a New Theory', supra note 1.

${ }^{26}$ Zamboni, supra note 15 , at 2.

${ }^{27}$ Ibid.

28 Wintgens 'Legislation as an Object of Study', supra note 1, at 37; Wintgens 'Legisprudence as a New Theory', supra note 1, at 19-22. 
political material into consideration in the interpretation of positive norms. ${ }^{29}$ It is a matter of fact that the nature of criminal law reflects the political realities; thus, in a liberal political culture, often, a liberal criminal law could be adopted. ${ }^{30}$

Likewise, in authoritarian regimes, authoritarian criminal law is adopted. ${ }^{31}$ However, in as much as the politics appear to be dominating at the dynamic level, which is the lawmaking process, there is also an aspect of specialisation that helps regulate the government based on such law, as they cannot be easily manipulated by the political process. ${ }^{32}$ Therefore, when the lawmaker adopts a policy as a prelude to legislation, the lawyers, drafting the bill, are guided by such super principles as rule of law and constitutionalism, or principle of legality, the prohibition of excess, and similar other doctrines. ${ }^{33}$

The formal validity of the law is relevant only for the coming into force of a certain norm; however, its continued existence is justified by its coherence with reality. ${ }^{34}$ The rule must be relevant in the real world and must continue to conform to the facts it is meant to address.

${ }^{29}$ Ornowska, supra note 15 , at 260, 267-268.

30 Simeneh Kiros Assefa and Cherinet Hordofa Wetere (2019), 'Governing Using Criminal Law: Historicising the Instrumentality of Criminal Law in Ethiopian Political Power', 31 J Eth L (forthcoming); Samuel Rodriguez Ferrandez 'Legislative Evaluation in Spain: Its Necessary Application in the Approval of Criminal Law Reform' in Adan Nieto Martin and de Marta Munoz de Morales Romero (eds), Towards a Rational Legislative Evaluation in Criminal Law (Springer 2016).

${ }^{31}$ Simeneh and Cherinet 'Governing Using Criminal Law', supra note 30.

32 Zamboni, supra note 15, at 134-136.

${ }^{33}$ Humberto Ávila (2007), Theory of Legal Principles (Springer) 96-102; Council of Ministers Working Directive 1996 EC (in Amharic, 'CM Working Directive'), Annex 1 'Directive on manner of preparation of documents to be submitted to the Council of Ministers', art 8.; Guideline Circular on the Preparation and Form of Draft Laws to be submitted to Council of Ministers (dated Tikimt 27, 2011 EC).

34 Kelsen argues that validity is 'formal' and effectiveness is 'substantive'; thus, 'effectiveness is condition of validity'. Kelsen, Pure Theory of Law, supra note 1, at 10-11, 209-213; Hans Kelsen (1949), General Theory of Law and State (Anders Wedberg tr, Cambridge UP) at 121; Alexy describes is as 'social efficacy'. Alexy, supra note 1, at 13-19; Wintgens 'Legisprudence as a New Theory', supra note 1, at $13 \mathrm{ff}$. 


\section{The Criminal Lawmaking Power and Federal Legislation}

\subsection{The criminal lawmaking power}

The pre-legislative phase first relates to the power and responsibilities of the government regarding lawmaking. The powers of the Federal Government are listed under article 51 of the FDRE Constitution. The rest of the powers are given to the regional states. Based on this allocation of power, the lawmaking power of the House of Peoples' Representatives (the HoPR) is provided for under article 55. The House is expressly vested with the power to 'enact a penal code' which Hans Kelsen would call this immediate justification for the existence of such law. ${ }^{35}$ This is provided for under article 55(5).

The proper reading of this provision entrusts the House with the power to adopt a criminal law, but its authority springs from the provisions of FDRE Constitution, article 55(5), and it shall enact such criminal law in a code form. Should it find it necessary to criminalise further conducts, it may do so by amending such code. A constitutional power of a government cannot spring from two different constitutional provisions, based on the nature of the constitutional economy of words.

However, article 55(1) of the FDRE Constitution is considered a catch-all basket to be invoked whether there is a provision authorising particular legislation or not. ${ }^{36}$ Several special penal legislation and administrative regulatory legislation containing penal provisions were adopted invoking the provisions of article 55(1). They include: the Anti-Terrorism Proclamation No 652/2009, Banking Business Proclamation No 592/2008, Revised AntiCorruption Special Procedure and Rules of Evidence Proclamation No 434/2005, and Prevention and Suppression of Money Laundering and the Financing of Terrorism Proclamation No 657/2009. Even when there is specific provision authorising a particular type of legislation, article 55(1) is invoked as a justification for the adoption of such legislation. Thus, while the provisions of article 55(11) authorise the House to legislate on tax matters, Value Added Tax Proclamation No 285/2002, Income Tax Proclamation No 286/2002 and the Stamp Duty Proclamation No 110/1998 were adopted invoking the provisions of articles 55(1) and 55(11). Likewise, Corruption Crimes Proclamation No 881/2015 invoked article 55(1) and (5).

\footnotetext{
${ }^{35}$ Kelsen, Pure Theory of Law, supra note 1, at $221 \mathrm{ff}$.

${ }^{36}$ FDRE Const, art 55(1) provides that 'The House of Peoples' Representatives shall have the power to legislative in all matters assigned by this Constitution to the Federal jurisdiction'.
} 
The provisions of article 51 deal with public administrative matters vested on the Federal Government. Thus, article 55(5) authorising the HoPR to adopt a penal code is not, ideally, an unlimited power, but limited by its purpose as provided for under article 51. The provisions of article 55(1) should be understood to helping the Federal Government discharge its obligations and achieve its objectives as provided for under article 51. Therefore, article 55(1) does not authorise the adoption of penal provisions in every administrative bill. Even Corruption Crimes Proclamation $881 / 2015$ could only be justified by article $55(5)$ as an amendment to the Criminal Code.

\subsection{The duty to declare criminal norms to the public}

The principle of legality requires that the law be 'declared'. In defining the legislative power of the HoPR, the Constitution provides that the HoPR may adopt a penal code. ${ }^{37}$ Such code is adopted in the form of a proclamations and is published in the official Negarit Gazeta. Article 2(2) of the Federal Negarit Gazeta Establishment Proclamation No 3/1995, provides that '[a]11 laws of the Federal Government shall be published in the Federal Negarit Gazeta'. Even when a breach is said to be committed against 'legislation issued by an authorised public organ', it must be on that is 'duly published in the Federal Negarit Gazeta'. ${ }^{38}$ This is not a definition of what law is in the country, but how the criminal law should be published as notice to the public, short of which it does not constitute a criminal norm.

\subsection{Federal legislation rules}

The principal legislative rule is found in the Constitution. Article 55 provides for the lawmaking power of the HoPR, and article 55(5) specifically governs the criminal lawmaking power of the House. The provisions of article 77(1) provide that the Council of Ministers may initiate bills on matters that fall under the jurisdiction of the Federal Government. ${ }^{39}$ These provisions are jurisdictional matters; and, their implementation is governed by subsidiary rules, such as, Proclamation No 470/2005 ${ }^{40}$ and

${ }^{37}$ FDRE Const, art 55(5).

${ }^{38}$ Crim C, art 343(1). Also see Jean Graven 'The Penal Code of the Empire of Ethiopia' (1964) 1 J Eth L 267, 287.

${ }^{39}$ FDRE Const, art 51 lists those powers that fall under the jurisdiction of the Federal Government and art 55 provide for the lawmaking power on those subjects.

40 The earlier legislation rules include, House of Peoples' Representatives Legislative Procedure Proclamation No 14/1995, House of Peoples' Representatives Legislative Procedure (Amendment) Proclamation No 33/1995, and Proc No 271/2002, supra 
Regulations No 6/2015 adopted by virtue of article 59 of the FDRE Constitution. This includes the Council of Ministers Working Directive. It governs the initiation of bills and adoption procedure in the Council of Ministers. ${ }^{41}$

As the political system is dominated by the executive, ${ }^{42}$ the Council of Ministers is the most important government organ in the bill initiation phase of primary legislation and the issuance of subsidiary legislation (regulations and directives). The Council of Ministers Working Directive is thus the most influential legislation rule. This assertion is supported by two facts. First, the principal entity empowered to initiate bills is the Government. ${ }^{43}$ However, "the House of Federation (the HoF), the Speaker, Federal Supreme Court, Committees of the House, Members of the House, [and] other governmental institutions directly accountable to the House' are granted the power to initiate bill. ${ }^{44}$ This is the case since $2002 .{ }^{45}$

Likewise, the Council of Ministers Working Directive authorises all government agencies to initiate policies and bills in their area of competence. ${ }^{46}$ However, none of those legislation that are discussed in this article (with regard to Ethiopian criminal law-making) is initiated by the House or its members. The Federal Government agencies (Council of Ministers, in particular) are the most important source of legislation and, de facto, nearly the sole source of bills.

note 4 . The discussion is made based on the applicable legislation rule at the time of the adoption of a particular legislation. While the CM Working Directive, supra note 33, stood fast for so long, the HoPR rules of lawmaking are changed substantially and repeatedly.

${ }^{41}$ The CM Working Directive, supra note 33, does not state the authority on the basis of what it is adopted. There does not seem to be a constitutional mandate to adopt such a directive.

42 Assefa Fiseha 'Legislative-Executive Relations in the Ethiopian Parliamentary System: Towards Institutional and Legal Reform' in Jaap de Visser, Nico Steytler, Derek Powell and Ebenezer Durojaye (eds), Constitution-Building in Africa (Nomos 2015).

${ }^{43}$ Proc No 470/2005, supra note 2, art 6(2); The House of Peoples' Representatives of the FDRE Rules of Procedure and Members' Code of Conduct Regulations No 6/2015, art 51(1) - (3).

${ }^{44}$ Ibid.

${ }^{45}$ Proc No 271/2002, supra note 4, art 4(2).

${ }^{46}$ CM Working Directive, supra note 33, art 38(1); Proc No 470/2005, supra note 2, art 6(3). However, 'financial draft laws' are exclusively initiated by the government. Id., art 6(4); Regulations No 6/2015, supra note 43, art 51(3). 
Second, the Council of Ministers Working Directive governs the essential part of the pre-legislative phase, such as, which organ initiates a bill, the adoption of a policy in order to guide the drawing up of the bill, ${ }^{47}$ the drafting instructions to be given to the experts drafting the bill from the concerned administrative agency, the required type and level of enquiry, the required format of drawing up of the bill, the requirements of conformity with other legislation and doctrines including the Constitution, ${ }^{48}$ and the nature of the debate to be had and approval by the Council. ${ }^{49}$ In comparison, the legislation rules of the House are limited to the legislation stage in the House. The House limited its power of hearing and enquiry. ${ }^{50}$

Apart from what the law has provided for, there are instances where the Council of Ministers dictated a particular type of rule. For instance, in the adoption process of the Commercial Registration and Business Licensing Proclamation No 980/2016, members of the House enquired whether it was reasonable to keep those (severe) penal provisions. The resource persons replied that they understand the moral dilemma the judges face to impose such criminal punishment and had attempted to reduce the criminal punishments. However, the Council of Ministers rejected the proposal and decided to keep the provision as it had been. The provision was finally adopted as decided by the Council of Ministers. ${ }^{51}$

47 Art 38(5) gives the impression that bills emanate from a policy which is provided for under arts $30-36$.

${ }^{48}$ CM Working Directive, supra note 33, arts 34, 35, 42(5)(a), 46(1)(a), (b).

${ }^{49}$ Art 3 defines the duties and responsibilities of the Council of Minsters one of which is deliberations of bills and passing over to the House of Peoples' Representatives. art $3(1)(d)$.

${ }^{50}$ For instance, the full House hearing is limited to reports and recommendations of the committees. See Section 5.3.5.2.

51 'Minutes of Public Hearing Organized by the Commercial Affairs Standing Committee on the Commercial Registration and Business License Bill, 5 July 2016' (later adopted into law as Commercial Registration and Business Licensing Proclamation No 980/2016, in Amharic) at 9, 10; 'Minutes of Meeting of Commercial Affairs Standing Committee with Resource Persons from Ministry of Trade on the Commercial Registration and Business License Draft Amendment Bill, 29 June 2016' (later adopted into law as Proc No 980/2016, in Amharic) at 12-13. Commercial Registration and Business Licensing Proclamation No 686/2010, art 60(1), engaging in business without a valid (renewed) commercial license were made punishable with 7 to 15 years imprisonment, fine Birr 150,000-300,000 and confiscation of the property used for such activity. This punishment is maintained in the new Proc No 980/2016, art 49(2). 
The proclamations adopted by the House sometimes authorise the adoption of Regulations by the Council of Ministers and directives by the respective agencies. Those regulations and directives are required to comply with the requirements of the Proclamation. To that extent, the proclamations are also legislative rules.

\section{Initiation of Bills and the Lawmaker's Pre-legislative Investigations and Deliberations}

\subsection{Institutions initiating bills}

All legislative rules authorise government agencies to initiate a bill in the area of their competence. ${ }^{52}$ However, the Council of Ministers Working Directive requires that when a criminal provision is introduced in a bill, the (then) Ministry of Justice would have to be consulted. ${ }^{53}$ The designation of institutions to participate in a particular subject matter is for reasons of specialisation. Thus, the Ministry of Justice is the Federal Government advisor on legal matters. ${ }^{54}$ However, the Ministry of Justice did not participate in several regulatory legislative preparations.

For instance, in those tax legislation that contained serious penal provisions, such as the VAT and Income Tax Proclamations, the principal actors were the Ministry of Finance and Economic Development (MoFED) and the Ministry of Revenue, respectively. ${ }^{55}$ The Government Finance and Property Administration Proclamations were drawn up by MoFED. ${ }^{56}$ The

52 Proc No 470/2005, supra note 2, art 6(3), (4); Regulations No 6/2015, supra note 43, art 51(2)(d); CM Working Directive, supra note 33, arts 30, 38(1).

${ }^{53} \mathrm{CM}$ Working Directive, supra note 33, art 42(5).

${ }^{54}$ Definition of Powers and Duties of the Executive Organs of the Federal Democratic Republic of Ethiopia Proclamation No 4/1995, art 23(1); Reorganisation of the Executive Organs of the Federal Democratic Republic of Ethiopia Proclamation No 256/2001, art 15; Federal Attorney General Establishment Proclamation No 943/2016, art 6(2).

${ }^{55}$ Both the Ministry of Revenue and MoFED each established a Tax Reform Program Office which had worked on the VAT and the Income Tax Proclamation, respectively. 'Reports and Recommendation of Budget and Finance Affairs, and Legal and Administrative Affairs Standing Committees for the Adoption of the Value Added Tax Draft Bill into Law, Recommendation No 1/1994' (later adopted into law as Proc No 285/2002); 'Brief Explanatory Memorandum on Income Tax Draft Bill' and the accompanying 'Technical Document Containing Core Issues in the Draft Income Tax Bill, May 2002 (later adopted into law as Proc No 286/2002).

56 'Brief Explanatory Memorandum on the Revised FDR Ethiopia Procurement and Property Administration Draft Bill, April 2009'; 'Brief Explanatory Memorandum on the Revised Federal Government Finance Administration Draft Bill, April 2009’; 
drafters and resources persons of the former Anti-Terrorism Proclamation were only from the National Intelligence and Security Services, the Federal Police and the Prime Minister's Office. ${ }^{57}$ Likewise, Money Laundering and Financing of Terrorism Proclamation No 657/2009 was drafted by the National Bank of Ethiopia, ${ }^{58}$ and Corruption Crimes Proclamation 881/2015 was drafted by the Federal Ethics and Anti-Corruption Commission. ${ }^{59}$

For the most part, each of the penal provisions contained in those piecemeal legislation are redundant, and in some instances, significant modifications to those provisions in the Criminal Code. The Ministry of Justice (currently, the Federal Attorney General's Office) is most suitable to initiate and harmonize the revision of the penal provisions and to see to it that they are rationally integrated to the Code or help achieve the intended objective, and most importantly, to better assess the social and political impact of such provisions. Where there are changes to the existing rules, it is only expanding the scope of the criminal conduct and increasing the punishment. ${ }^{60}$ The institution that is suitable to address the matter was not

'Minutes of Meeting with Experts on the Revised FDR Ethiopia Finance Administration and Procurement and Property Administration Draft Bills Organised by Budget and Finance Affairs Standing Committee' (later adopted into law as Proclamation No. 648/2009 and Proclamation No. 649/2009, respectively); 'Report and Recommendation of the Budget and Finance Affairs Standing Committee that the FDR Ethiopia Procurement and Property Administration draft bill be adopted into law, Recommendation No 12/2001, 2 July 2009'.

57 'Brief Explanatory Memorandum on the Anti-Terrorism Draft Bill' (later adopted into law as Proc No 652/2009); 'Brief Minutes of Hearing with Stakeholders on the AntiTerrorism Draft Bill Organised by Justice and Administrative Affairs, and Foreign, Defence and Security Affairs Standing Committees, 24 June, 2009' (later adopted into law as Proc No 652/2009).

58 Records show that the representative from the Ministry of Justice would be in attendance of the house committee hearing but he was absent. 'Minutes of Public Hearing on Money Laundering and Financing of Terrorism the Draft Bill and Explanatory Memorandum, Organized by the Budget and Finance Affairs, and Law and Administrative Affairs Standing Committees, 30 October 2009' (later adopted into law as Proc No 657/2009, in Amharic). Even though at the Committee hearing the resource person from the NBE asserts that opinion was sought from the Ministry of Justice that is not reflected in any record.

59 'Minutes of Meeting of Law, Justice and Administrative Affaires Standing Committee with Federal Ethics and Anti-Corruption Commission and the Ministry of Justice authorities on Corruptions Crimes Draft Bill Drawn up by the Ethics and AntiCorruption Commission 10 December 2014' (later adopted into law as Proc No 881/2015).

${ }^{60}$ Simeneh Kiros Assefa and Cherinet Hordofa Wetere (2017), 'Over-Criminalisation': 
made a part of the process (in the proclamations indicated in the preceding paragraph) which certainly compromises the quality of the work. If there is no sufficient investigation conducted to establish the facts regarding the failed social interactions, no rational solution can be suggested. Therefore, penal provisions in these proclamations lack both epistemic and objective rationality.

\subsection{The lawmaker's duty to investigate into facts}

The most important pre-legislative activity is an investigation into the failed social interaction and contextualisation of the problem which Luc Wintgens referred to as 'the principle of alternativity'. ${ }^{61}$ When the hermeneutic view of the legislature is argued for, it is a quintessential instrumentalist view of law; ${ }^{62}$ the law is used to address specific social, political and economic objectives in want of legislative intervention. It is to find a proper link between legislation and the value it is intended to pursue that the investigation into the facts is required. ${ }^{63}$

The background study of a given legislation needs to contain several themes, including, identifying the failed social interaction, the alternative measures available to the legislature, ${ }^{64}$ and whether legislative intervention is warranted. ${ }^{65}$ If there was a norm governing the social relation, it should also show how such norm fails, ${ }^{66}$ and in the instant case, if a criminal norm is sought, in conformity with the principle of ultima ratio, it should also indicate that those identified alternative measures have failed to achieve the intended purpose and criminalisation is necessary.

The Council of Ministers Working Directive requires that proposal and research documents submitted to the Council must be based on sufficient understanding of the subject matter, and include all information necessary to

A Review of Special Penal Legislation and Administrative Penal Provisions in Ethiopia $29 \mathrm{~J}$ Eth L 49, 78-81.

${ }^{61}$ Wintgens 'Legisprudence as a New Theory', supra note 1, at 11; Ferrandez, supra note 30 , at 79 .

62 Wintgens, 'Legislation as an Object of Study', supra note 1, at 13; Brian Z Tamanaha, The Law as a Means to an End: Threat to the Rule of Law (Cambridge UP 2006).

${ }^{63}$ Wintgens, 'Legislation as an Object of Study', supra note 1, at 12-15; Oliver-Lalana, supra note 11, at 135-159; Ferrandez, supra note 30, at 79.

64 Philippe Thion 'Questioning Alternatives to Legal Regulation' in Wintgens LJ, Legislation in Context: Essays in Legisprudence (Ashgate 2007) at 96-99.

${ }^{65}$ Wintgens 'Legislation as an Object of Study', supra note 1, at 12-13.

${ }^{66}$ Wintgens calls this 'normative density'. Ibid. 
decide on the public interest. ${ }^{67}$ The decision of the Council should reflect 'all government policies and procedures are thoroughly examined or looked into' ${ }^{68}$ Likewise, the HoPR Regulations require that the explanatory memorandum should state 'the necessity of the draft law' and 'the object of the bill' ${ }^{69}$

The various bills including those indicated in Section 4.1 were drawn up by different government agencies, and their knowledge of the rules on legislation and legislative expertise are of varying degrees. Thus, the practice of compliance with those requirements is not consistent. ${ }^{70}$ Several bills were adopted since the adoption of modern legislation rules in 2002. It is in response to such state of affairs that the Legislative Drafting Manual 2010 EC (in Amharic) was prepared. The Draft manual provides that where a criminal punishment is provided for, it should provide for 'proportional and clear penalty'. It prohibits drawing up provisions making preference to severe penalty. ${ }^{71}$

\subsection{Rationality of law, and of the lawmaker}

The proper link between the content of the idea of the relationship between law and politics, on the one hand, and the legislative rules on the other is the rationality of the legislature. In the insider view of lawmaking, the lawmaker is following rules as the judge does -the rules of legislation. The outsider view of lawmaking is addressing specific social, economic and political objectives. The legisprudential view of lawmaking is hermeneutic view. Consequently, rationality in legisprudence is about the aspiration to make 'good laws', ${ }^{72}$ which is depicted in the organisation, structure, and

${ }^{67} \mathrm{CM}$ Working Directive, supra note 33, art 5(5).

${ }^{68}$ Id., art 5(6). [Author's translation]

${ }^{69}$ Regulations No 6/2015, supra note 43, art 51(10)(a), (b).

70 The draft Press Proclamation was adopted before the adoption of the legislation rules, other than the Transitional Government Charter. The preparatory material only compiles the provisions contained in the Civil and Penal Codes relating to expression. There was no explanatory memorandum attached to it, nor a justification why Ethiopia needed such regulatory legislation containing severe penal provisions on the press.

${ }^{71}$ Legislative Drafting Manual 2010 EC (Draft, in Amharic), art 71(12).

${ }^{72}$ Fuller, supra note 1, at 3-11. Wintgens reduces rationality to a choice to make 'good laws' except it is bounded by such time and circumstances. Wintgens 'Legisprudence as a New Theory', supra note 1, at 22; Wintgens 'Bounded Rationality', supra note 1, at 6,8 . 
presentation of the positive law. ${ }^{73}$ The rationality of the law is seen both in the substantive and the formal requirements of the lawmaking process. It is all about the coherence of the legal system, legal doctrines, principles and rules, and making sense in the application.

The legislature is required to pursue a 'good' lawmaking process. This is principally done by examining the legislative duties of the legislature in enquiring into the facts demanding legislative intervention, in the preparation of a bill (or examining a bill initiated by another organ) and in the lawmaking debate in the pre-legislation, and reviewing the law made in post-legislation. This is done based on the existing legislation rules, the nature of lawmaking and the practice of lawmaking.

\section{Criminal Legislation with No Background Study}

The criminal law includes the Criminal Code, special penal legislation, and administrative regulatory legislation containing penal provisions. They all are adopted by the HoPR. In several of those legislation, including the Criminal Code, there is no background study justifying those legislative actions. For several of these bills, there were only explanatory memoranda. Even when these legislation were subsequently amended, no implementation information was presented. ${ }^{74}$

\subsection{The Vagrancy Control Proclamation}

Vagrancy had been criminal conduct in Ethiopia for more than a halfcentury, first by special legislation, then in the 1957 Penal Code. ${ }^{75}$ However, special legislation is adopted while there was such a provision in the Penal Code. The central justification for the adoption of the special legislation was treating it as a special crime with special procedure 'in order to permanently dispel the threat of vagrancy' and other crimes. ${ }^{76}$ The bill was drafted by the Ministry of Federal Affairs and the Ministry of Justice. ${ }^{77}$ The explanatory memorandum to the bill asserts that researches done by the Federal Police indicate that crime of vagrancy and related crimes were growing and were

\footnotetext{
${ }^{73}$ Wintgens 'Bounded Rationality', supra note 1, at 6-12.

${ }^{74}$ Simeneh Kiros Assefa (2018), 'Walking in the Dark: Lack in the Use of Criminal Statistics for Public Policy and Legislative Action' 12 Mizan LR 371, 387-399.

${ }^{75}$ Art 471. This is also taken over by the Crim C, art 477 .

76 The Vagrancy Control Proclamation No 384/2004, preamble, para 2.

77 'Reports and Recommendations of Law and Administrative Affairs, and Social Affairs Standing Committees Regarding the Vagrancy Control Draft Bill', 21 January 2004 (in Amharic) at 2.
} 
matters of urgent attention. ${ }^{78}$ The media also portrayed vagrancy as a serious problem. ${ }^{79}$ However, no evidence was presented in support of the bill; nor was such evidence presented at the House Committee hearing. ${ }^{80}$

The bill focuses on two matters. On the procedural aspect, it adopts the special procedure of sorts - granting power to the police to detain suspects and to detain them without bail which forms part of the final bill. ${ }^{81}$ On the substantive part of the law, the punishment is made severe and those conducts covered by the Vagrancy Proclamation are not new conducts but conducts punishable in the Penal Code with fine or few days detention. ${ }^{82}$ There were discontents regarding the necessity of the bill and its motives. Some opine that the bill was meant to muzzle the opposition political parties. ${ }^{83}$ This may be gathered from the news reports.

On April 17, 2001, Addis Ababa University students had a meeting with the Minister of Education demanding academic freedom and other rights. The meeting came to an end without agreement, and on the following day, the students staged protest demonstration. Youngsters outside the university campus had joined the students, as a consequence of which the security forces 'overreacted'. Several students died and some public institutions were set ablaze by unidentified individuals. ${ }^{84}$ The news reports blamed opposition

78 'Explanatory Memorandum on Vagrancy Control Draft Bill' (later adopted into law as Proc No 284/2004) at 1, 4.

79 'Millions worth of asset damaged and looted by hooligans', Addis Zemen, Addis Ababa, April 20, 2001 (in Amharic); 'Ethiopian Telecommunication Corporation reported property worth Birr 50 million damaged', Addis Zemen, Addis Ababa, April 21, 2001 (in Amharic).

80 The bill was drafted by the Ministry of Federal Affairs and the Federal Police; 'Explanatory Memorandum on Vagrancy Proclamation', supra note 78, states that researches conducted by the Federal Police indicate that vagrancy is a serious problem. However, the police did not have such recording keeping division until 2006 EC (2013/14). Simeneh 'Walking in the Dark', supra note 74, at 377.

81 Proc No 384/2004, supra note 76, art 4, after defining what conducts constitute vagrancy, imposes a heavier penalty. Further, art 6(1) authorises the police to effect arrest without warrant, and sub-art (3) provides that such a person suspected of vagrancy may not be released on bail.

${ }^{82}$ Simeneh and Cherinet 'Overcriminalisation', supra note 60, at 79-80.

83 'Minutes of Public Hearing Organized by Legal and Administrative Affairs, and Social Affairs Standing Committees on the Vagrancy Control Draft Bill 12 January 2004' (in Amharic, later adopted into law as Proc No 384/2004) at 12-13.

${ }^{84}$ See supra note 79. 
political parties and certain human rights groups for inciting the incident. ${ }^{85}$ These incidents were found to be good excuses for the adoption of the bill into law.

At the public hearing on the draft bill, three points were outstanding: vagrancy reflects the socio-economic problem which could only be addressed by adopting a good economic policy, not by criminal law; second, the criminalisation of vagrancy is directed against the opposition political parties; and third, the conducts that are criminalised are already criminalised in the Penal Code, except where the punishment is made severe and it is made status crime. ${ }^{86}$ Yet, the Committee had recommended the adoption of the bill into law by the full House without any modification. ${ }^{87}$ As those issues were not made part of the report of the Committee, records do not show the full House had discussed those issues. The bill was adopted into law as it was.

\subsection{Money Laundering and Financing of Terrorism Proclamation}

The bill on Money Laundering and Financing of Terrorism is drawn up by the National Bank of Ethiopia. ${ }^{88}$ One thus would expect the National Bank of Ethiopia would present information it has gathered in the course of banking services showing problems relating to money laundering. However, the explanatory memorandum to the bill does not contain any data. ${ }^{89}$ At the hearing with the two pertinent Standing Committees, the resource persons

${ }^{85}$ All the press releases made by the Federal Government, the Federal Police and the Ministry of Education blame the cause of the incident on the All Amhara People Organisation (AAPO) and Ethiopian Democratic Party (EDP) and Ethiopian Human Rights Council (EHRCO) employing vagrants to implement their 'policies'. Of those 31 people who, the Government admitted, died during clash, the police also alleged that 9 of them had prior criminal records. ENA 'Police Announces 31 People Died as a Result of Clash Following Students' Protest' Addis Zemen, Addis Ababa, April 24, 2001 (in Amharic). Also see, ENA 'Police reported recovering a part of assets looted' Addis Zemen, Addis Ababa, April 21, 2001 (in Amharic).

86 'Minutes of Public Hearing on Vagrancy Proclamation', supra note 83, at 10-14.

87 'Report and Recommendation on Vagrancy Proclamation', supra note 77.

${ }^{88}$ The resource persons at the public hearing stated that the bill had been drawn up with the assistance of the Ministry of Justice. However, the explanatory memorandum was drawn up and submitted by the National Bank of Ethiopia (NBE). National Bank of Ethiopia 'Explanatory Memorandum on the Bill on Money Laundering and Financing of Terrorism' (2001 EC, in Amharic). All the three resource persons present at the discussion were from the NBE. 'Minutes of Public Hearing on the Draft Bill on Money Laundering and Financing of Terrorism organized by the Budget and Finance, and Law and Administrative Standing Committees' October 31, 2008.'

${ }^{89}$ Explanatory Memorandum by the NBE, supra note 88. 
from the National Bank of Ethiopia asserted that there had never been a criminal prosecution on money laundering until the date of discussion..$^{90}$ However, other related questions, such as the reasons including attorneys in the list of accountable persons, were answered by conjuncture. ${ }^{91}$

The explanatory memorandum does not state the reasons for such action but, it appears to have focused on the enforcement of the international conventions and resolutions. ${ }^{92}$ The bill rather does three things: it imposes an obligation on specified individuals and entities, including lawyers, referred to as 'accountable persons' to report suspicious activities relating to their clients, criminalising possession of unexplained property and international cooperation.

\subsection{Tax Legislation}

There were tax crimes included in the Penal Code. It is despite such provisions that those tax legislation were adopted containing penal provisions. The penal provisions contained in those tax legislation, such as the Income Tax Proclamation No 286/2002, Value Added Tax Proclamation No 285/2002, were not commented on in the explanatory memorandum. ${ }^{93}$ There is no mention of the tax crimes stated in the Penal Code; nor was there explanation why the tax crime provision in the Penal Code was believed to have failed to help achieve the objectives sought in the penal provisions of the draft bills. No record shows penal provisions in the Income Tax Proclamation were discussed by the Committee to which the matter was referred for a thorough examination. In the discussion on the Value-Added Tax Proclamation, the experts from MoFED suggested the penal provisions that were already in the Income Tax draft bill be included in the VAT

90 'Minutes of Public Hearing on Money Laundering Draft Bill', supra note 58, at 10 12. 'Minutes of the Meeting of the Budget and Finance, and Law and Administrative Standing Committees on the Draft Bill on Money Laundering and Financing of Terrorism 21 October 2008' (later adopted into law as Proc No 657/2009)

${ }^{91}$ Id., at 11.

92 Explanatory Memorandum by the NBE, supra note 88, at $2-4$, discusses the various international conventions and UN Security Council Resolution and such related requirements.

93 'Explanatory Memorandum on Income Tax Bill', supra note 55; the penal provisions were incorporated into the VAT Proclamation later after the experts made such recommendation at the Committee hearing. 'Modifications made on the Value Added Tax Draft Bill' (later adopted into law as Proc No 285/2002) para 4. 
Proclamation too, and the Committees agreed. The penal provisions of the Income Tax bill were included in the VAT bill and adopted into law. ${ }^{94}$

The principal purpose of the penal provisions is to 'maximize revenue'. ${ }^{95}$ The explanatory memorandum states that the objective of the revision the law and inclusion of severe penal provision is 'to prevent tax crimes and to have deterrence effect'. ${ }^{96}$ While those same penal provisions were reproduced in the Value-Added Tax bill, the principal discussion was on the effect of replacing the sales tax with such VAT and the constitutional power to adopt a VAT Proclamation. ${ }^{97}$ There was only a decision that 'penal provisions similar to that of income tax bill' be incorporated. There is no record of discussion regarding the fate of those provisions in the Penal Code, the effect and content of those penal provisions and how they relate to the general principles of the criminal law.

The Federal Tax Administration Proclamation was adopted in 2016. Regarding the penal provisions, this proclamation does two things: it lists almost all tax-related crimes in one bill in an encyclopedic manner; it also maintains other tax-related penal provisions ${ }^{98}$ with minor modifications ${ }^{99}$ It elevated the directives indirectly, not unwittingly, to criminal law status. ${ }^{100}$

\subsection{The Anti-Terrorism Proclamation}

In response to the UN Security Council Resolution 1317(2001), Ethiopia held that it had sufficient law to address acts of terrorism. ${ }^{101}$ Ethiopia, however, adopted the Anti-Terrorism Proclamation No 652/2009, changing

94 Ibid. 'Minutes of Meeting of the Economic Affairs and Legal Affairs Standing Committees with Resource Persons on the Value Added Tax Draft Bill', 7 November 2001' (later adopted into law as Proc No 285/2002).

95 'Minutes of Meeting on VAT Proclamation', Id., at 11.

96 'Explanatory Memorandum on Income Tax Bill', supra note 55, 2.

97 'Minutes of Meeting on VAT Proclamation', supra note 94; 'Report and Recommendation of Economic Affairs and Legal Affairs Standing Committees Regarding the Value-Added Tax Bill, 7 December 2001' (in Amharic).

98 Federal Tax Administration Proclamation No 983/2016, art 116(2) provides that where a single conduct is criminalised in different proclamations, each shall be prosecuted as a separate crime.

99 For instance, the punishment for violation the stamp duty rules is reduced from imprisonment 10 to 15 years under the Stamp Duty Proclamation No 110/1998, art 12(1) to 3 to 5 years under Proc No 983/2016, art 123(1) which is still unreasonable by any standard.

100 The tax laws provide that violation of the tax laws is a crime; and in its definition, it included directives as tax laws. Proc No 983/2016, supra note 98, art 2(36).

${ }^{101}$ Wondwossen Demissie Kassa (2013), 'Examining some of the raisons d'etre for the Ethiopian Anti-Terrorism Law’, 7 Mizan LR 49, 52. 
its initial stance on the ground that the then existing laws were not sufficient to deal with such 'heinous crime'. ${ }^{102}$ The bill was drafted by the National Intelligence and Securities Services Agency and the Federal Police. After defining terrorist acts, it grants almost unbounded power to those agencies regarding the investigation and matters relating to the prosecution of such crimes. The explanatory memorandum states that the existing rules were not sufficient to deal with the matter. ${ }^{103}$ It makes reference to international instruments for the definition of the crime and regarding Ethiopia's international obligation to adopt such a law. It does not state other reason that justify the adoption of the law.

The committee hearing was attended by standing committee members and a few ordinary members of the House. The resource persons were high ranking officials from the Ministry of Foreign Affairs, the Ministry of Defence, the National Intelligence and Security Services and the Ministry of Justice. ${ }^{104}$ Unlike other bills, there is no record of a public hearing, and bill was recommended for adoption into law by 17 to 6 votes of Committee members. ${ }^{105}$

The examination of the history of prosecution for terrorism reveals that there were two waves of action against alleged acts of terrorism. There were 214 individuals who were charged and convicted for terrorism between 1995 and 2004 in connection with the incidents in the transition period. ${ }^{106}$ For instance, in Beyan Ahmed, et al, ${ }^{107}$ Abdulkader Mohammed, et al, ${ }^{108}$ Ziyad

\footnotetext{
102 'Explanatory Memorandum on the Anti-Terrorism Draft Bill', supra note 57.

${ }^{103}$ Id., at 17-19.

104 'Minutes of Hearing with Stakeholders', supra note 57.

105 'Report and Recommendation of Law and Administrative Affairs, Foreign, Defence and Security Affairs Standing Committees Regarding the Anti-Terrorism Draft Bill, Recommendation No 8/2001, 7 July 2009'.

106 One of the witnesses in Alemayehu stated this clearly. Central Public Prosecutor $v$ Alemayehu Tolosa and Ketma Abdeta (29 November 2004, Crim File No 01153 Central High Court). There were also other cases, including Central Public Prosecutor v Ahmed Nour (26 March 2004, Crim File No 01121 Federal High Court); Public Prosecutor v Yahiya Zekaria (23 July 2004, Crim File No 00586 Federal High Court); Public Prosecutorv Mohammed Abdella (15 June 2004, Crim File No 01137 Federal High Court); Public Prosecutor v Ousman Abdella (10 November 2004, Crim File No 01397 Federal High Court); Central Public Prosecutor v Jenda Mussa (6 February 2004, Crim File No 01114 Federal High Court.

${ }^{107}$ Public Prosecutor v Beyan Ahmed, et al, 7 defendants (15 October 2004, Crim File No 03139 Federal High Court).
} 
Muhammed, ${ }^{109}$ and Alemayehu Tolosa ${ }^{110}$ defendants were charged for conducts the OLF and IFLO did after exiting the Transitional Government of Ethiopia Council of Representatives. Terrorism was alleged in the context of genocide. However, the principal conduct (they were charged for and convicted) referred to those acts committed while the groups were members of the Transitional Government in May and June 1992. ${ }^{111}$ The case of Dinkinesh Deressa ${ }^{112}$ disposed of in 2005 only shows the continuation of such action of the Government. This was the first wave of prosecution for terrorism.

The second wave of anti-terrorism actions by the Government upon the adoption of the 2009 Anti-Terrorism Proclamation and the declaration of armed struggle by Ginbot-7 somehow coincided. The Government then declared two organisations terrorist organisations; the leadership of Ginbot-7 were charged in absentia and several of them were sentenced to death and many were sentenced to life imprisonment. ${ }^{113}$ If the prosecution for acts of terrorism was possible under the already existing 1957 Penal Code, the adoption of the Anti-terrorism law was unnecessary in the absence of factfinding showing otherwise.

${ }^{108}$ Public Prosecutor v Abdulkader Mohammed, et al, 7 defendants (16 January 2004, Crim File No 01392 Federal High Court).

${ }^{109}$ Public Prosecutor v Ziyad Muhammed Oumer (10 June 2004, Crim File No 01178 Federal High Court).

${ }^{110}$ Central Public Prosecutor v Alemayehu Tolosa and Ketma Abdeta (29 November 2004, Crim File No 01153 Central High Court).

111 The facts are stated in almost every case; but reports of the TGE Council of Representatives Enquiry Commission report is attached to Beyan Amhed case, supra note 107, as evidence which constituted only one count, count 10.

112 Public Prosecutor v Dinkinesh Deressa and Negassa Negussie (27 May 2005, Crim File No 13433 Federal High Court)

113 In Federal Public Prosecutor v Brigadier General Teferra Mammo Cherkos, et al, (46 defendants) (22 December 2009, File No 81406, Federal High Court) 5 defendants, Melaku Teferra, Dr. Birhanu Nega, Andargachew Tsige, Muluneh Eyuel, and Mesfin Aman, were sentenced to death; 33 were sentenced to life imprisonment and 2 were sentenced to 10 years rigorous imprisonment. The reason the court handed down the death sentence stated that the defendants were involved in similar conduct for which they had been pardoned. Because they were found in the same criminal conduct which shows they had no remorse and no legal ground to mitigate the punishment (ENA). 'Those Charged for Violating the Constitution by Force and Armed Violence were Sentenced to Death, Life Imprisonment and 10 Years Rigorous Imprisonment'. Addis Zemen, Addis Ababa, 23 December 2009 (in Amharic) at 1, 3 . 


\subsection{Administrative Regulatory Legislation Containing Penal Provisions}

Several administrative regulatory draft bills were accompanied by a short explanatory memorandum. They addressed regulatory matters, and their explanation focused on parts they deemed important - i.e., the regulatory part. While they contain penal provisions, the provisions were not discussed at all because they were not deemed 'essential' to the subject. Therefore, there is no comment on the penal provisions. The following proclamations illustrate the undue inclusion of penal provisions in regulatory legislation.

The Media Regulation Proclamations claimed to enforce the rights enshrined in the Constitution -freedom of expression- and it is administrative regulatory legislation. It can also be called penal legislation. There are penal provisions in the Criminal Code, including those unconstitutional provisions, such as, those establishing guilt by presumption and precluding contrary evidence. ${ }^{114}$ Thus, there was no need for further penal provision. The media regulatory legislation were meant to define such terms as, editor and producer in order to enhance the enforcement of the provisions of the Criminal Code. ${ }^{115}$ The explanatory memorandum did not touch upon the penal provisions; nor were such provisions discussed at the committee hearing.

The Consumer Protection Proclamation is meant to protect both consumers and traders/business firms from unfair trade practices. There are several prohibited practices and several of those conducts are criminally sanctioned. ${ }^{116}$ However, there was no explanation presented why those conducts were criminalized. Nor was there data presented to the House relating to the issue of criminalisation of conduct.

${ }^{114}$ Crim C, art 43(5) provides for proof of knowledge and consent of editor-in-chief of a periodical or producer or a broadcast by presumptions and precludes any 'proof to the contrary'.

115 The Criminal Code provides for criminal liability for conducts committed through the media and the Mass Media Proclamation defines those responsible persons in order to make the prosecution and conviction easier. 'Brief Explanatory Memorandum on Freedom of the Media and Access to Information Bill' (later adopted into law as Proc No 590/2008) at 12-14.

${ }^{116}$ For instance, art 49(1) punishes the abuse of dominance 'with a fine of $15 \%$ (fifteen percent) of his annual income or where it is impossible to determine the amount of his annual income with fine from birr 500,000 (five hundred thousand birr) to birr $1,000,000$ (one million birr) and with rigorous imprisonment from 5 (five) to 15 (fifteen) years.' 
The Federal Government Finance and Property Administration Proclamations (i.e., the Federal Government of Ethiopia Financial Administration and Ethiopian Federal Government Procurement and Property Administration bills) were drawn up by MoFED. ${ }^{117}$ Both bills were drawn up containing penal provisions. The crimes included are bribery, conspiracy to commit a crime, falsifying documents, disbursing illegal payment, illegal collection of payment, and other corrupt practices. ${ }^{118}$ The provisions are redundant with those contained in the Criminal Code. ${ }^{119}$ Yet, there was no mention of the need and justification for the inclusion of those provisions in the respective proclamation; nor was there a discussion in the committee hearings. ${ }^{120}$

\subsection{Legislation with Limited Background Study}

In some instances, there is an effort to present a background study investigating the facts that were said to require legislative intervention. However, few refer to the penal provisions in their comments. One such legislation is the Commercial Registration and Business License Proclamation 980/2016. The explanatory memorandum refers to the five years' practice and trade promotion policy. This relates to the essential part of the Proclamation. It attempted to reduce the punishment for engaging in business without a license but this was not accepted by the Council of Ministers. ${ }^{121}$

The crude comment of those provisions merely states that effort was made 'to elaborate' those penal provisions and to make them clear, ${ }^{122}$ while

${ }^{117}$ MoFED 'Explanatory Memorandum on the Revised Federal Government of Ethiopia Financial Administration, April 2009' (in Amharic); MoFED '[Explanatory Memorandum] Federal Government of Ethiopia Procurement and Property Administration, April 2009' (in Amharic).

118 Federal Government of Ethiopia Financial Administration Proclamation No 648/2009, art 70; and Ethiopian Federal Government Procurement and Property Administration Proclamation No 649/2009, art 77.

119 Crim C, art $404 \mathrm{ff}$. Those alleged illegal procurement and property management conducts were prosecuted under the provisions of the Criminal Code. See for instance Federal Attorney General v Zayid W/Gabriel, et al, (Federal High Court, File Nos 204242, 204153, 204154).

120 'Minutes of Meeting with Experts' on Proc No. 648/2009 and Proc No. 649/2009, supra note 56; 'Report and Recommendation of the Budget and Finance Affairs Standing Committee that the FDR Ethiopia Procurement and Property Administration Draft Bill be Adopted into Law' (Recommendation No 12/2001, 2 July 2009).

121 'Minutes of Meeting on Proc No 980/2016', supra note 51, at 12 - 14.

122 When the Commercial Registration and Business License Proclamation No 67/1997 
the bill does something else more -criminalisation of other conducts previously not prohibited, and increasing punishments. For instance, passing a commercial license to someone in any form practice is criminalised in article 49(4) of Proclamation No 983/2016, punishable with rigorous imprisonment from 5 to 10 years, fine from Birr 50,000 to 100,000 . Where such transfer is made to a foreign national, it is punishable with 7 to 15 years imprisonment and fine from Birr 200,000 to 300,000. ${ }^{123}$ The explanatory memorandum does not give any justification for such action; nor was it discussed at both committee and public hearings.

\section{Legislative Impact Assessment}

As rules of conduct, legislation are of prospective application. The investigation into the facts also reviews the impacts of the legislation when applied in the future. This is the normative, social, institutional, and economic impact of the legislation. The legislature needs to take into consideration not only the existing circumstances but also future circumstances so that the rules may remain valid for a reasonably longer period depending on the nature of the law. ${ }^{124}$ The Explanatory Memorandum to the Draft Constitution states that the criminal law has to be reasonably stable. ${ }^{125}$ However, it has to consider several factors which Wintgens refers to as 'contingencies'. ${ }^{126}$ First, it is in the nature of social facts that they change over time and, thus, the legislature needs to consider that possible future changes. However, such changes may also be the result of the legislation itself, therefore, the impact of such legislation or conduct of individuals should be reasonably predicted to have efficient rules. ${ }^{127}$

was adopted, no explanation was provided for including penal provisions in the regulatory provision. Yet again, not sufficient evidence was presented justifying the increased punishment when it was replaced with Proc No 686/2010, supra note 51. However, when it was replaced by Proc No 980/2016, supra note 51, there were researches apparently reviewing the practice.

${ }^{123}$ Proc No 980/2016, supra note 51, art 49(4).

${ }^{124}$ Once criminal laws are adopted, it appears there is no political will to repeal them. The current situation in Ethiopia is an exception where the newly formed Abiy Ahmed's Government understands the criminal law is used as a means of suppressing political dissent and any form of opposition, which starts with pardon, amnesty, and termination of charges.

125 'Explanatory Memorandum to the Draft Constitution', supra note 7, at 49-51.

${ }^{126}$ Wintgens 'Bounded Rationality', supra note 1, at 17-22.

${ }^{127}$ Id., at 23-26. 
Criminal legislation has an impact on the right of the individual. ${ }^{128}$ The Council of Ministers Working Directive requires certification that the intended legislation does not contradict the Constitution. This is one of the most pertinent aspects of the impact assessment because the lawmaker needs to make sure that such a bill does not unjustifiably impact the rights of the individual. The other important aspect of the enquiry is the effect of the rules on other interests, such as social consequences, institutional and other resource demands. ${ }^{129}$ The Council of Ministers Working Directive requires that the bill presented to the Council decision should not be one that would demand reform before or soon after its adoption into law. ${ }^{130}$ As an aspect of the investigation is to be conducted, there are different consultations required to be conducted by the proposing agency. Thus, before a matter is tabled in the Council for discussion, the agency is required to conduct consultation with relevant organs and consider their opinion. ${ }^{131}$

The consultation is principally within governmental institutions; ${ }^{132}$ but it may also be with the public and professional associations. ${ }^{133}$ Consultation is required to be made regarding financial matters, institutional matters, and or where there is a fundamental change in the existing rule. ${ }^{134}$ Further, it is specifically provided for in the Council of Ministers Working Directive that if a draft bill has an impact on other institutions' powers or has financial implications, the Ministry of Finance need to be consulted. ${ }^{135}$ Likewise, for penal provisions, the Ministry of Justice (currently Federal Attorney General) should be consulted. ${ }^{136}$

However, records do no show that any of those bills proposed and adopted into law had such investigation, nor was there a hearing on this subject. For instance, when the tax bills introduced imputed and non-fault liability, their effect on the business, on the government revenue, on individual freedom, is not discussed at all. When corruption offences were

${ }^{128}$ This conforms with the argument on rights as principium. Wintgens 'Legisprudence as a New Theory', supra note 1, at $11 \mathrm{ff}$.

${ }^{129}$ Wintgens 'Bounded Rationality', supra note 1, at 17-22; Ferrandez, supra note 30, at 85-99.

${ }^{130} \mathrm{CM}$ Working Directive, supra note 33, art 42(4)(b).

${ }^{131}$ Id., art 5(3).

${ }^{132} \mathrm{Id}$. , art 10(1)(a), (3).

${ }^{133}$ The consultation with the public and interest groups may be conducted only upon the Council of Minsters' approval. Id., art 10(2), (4).

${ }^{134}$ Id., art 9(2).

${ }^{135}$ Id., art 31(7)(e).

${ }^{136}$ Id., arts 42(1)(c), (5)(b). 
made non-bailable, their potential negative consequences were not foreseen. ${ }^{137}$

\section{The Duty to Maintain Coherence}

One of the fundamental principles of legislation is the principle of coherence. ${ }^{138}$ It connotes a wide range of things in the normative structure and legislative process. ${ }^{139}$ Wintgens discusses various types of coherence which are more or less similar to those discussed by Oliver-Lalana: linguistic, legal, social, goal and value rationality (coherence). Linguistic rationality relates to clarity of the law; legal rationality relates to the Kelsenian type of validity of rules; social rationality relates to the effectiveness of those norms; goal rationality relates to whether the intended means would help achieve the objectives sought and value rationality is about constitutional values. ${ }^{140}$ Without engaging in such details, we can, in the context of this article, discuss legisprudential coherence under two categories - the coherence of the legal system in general and coherence with reality.

\subsection{Coherence within the legal system (internal coherence)}

The principle of unity of the legal system requires that the norms in a legal system need to cohere with one another, irrespective of the category they fall under. ${ }^{141}$ Thus, in making or amending such law, the lawmaker is required to comply with the existing system of norms. The Council of Ministers Working Directive specifically requires that a bill be accompanied with a

137 The amendment makes corruption crimes bailable unless they are punishable by at least 10 years' imprisonment. However, several of the corruption offences were punishable by 7 to 15 years' rigorous imprisonment and by a wrong interpretation of the bail provision, those offences are also included in the non-bailable category that rendered the revision less useful.

${ }^{138}$ Wintgens 'Legisprudence as a New Theory', supra note 1, at 15-22. The other three principles of legislation include the Principle of Alternativity, the Principle of Normative Density and the Principle of Temporality. Id., at 11-15.

However, his theory of coherence was initially developed in 2002 and it relates to the judicial application of norms consisting of consistency as an element. He is coherence in five levels - consistency within the judicial decision, consistency of judicial decisions over time, consistency within the entire legal system, and consistency of decisions with reality.

139 Summers, Form and Function, supra note 12.

140 Oliver-Lalana, supra note 11, at 140-144.

${ }^{141}$ Ávila, supra note 33, at 84-91. Also see Summers, supra note 12, at 305-350. 
certification that it does not contradict with the Constitution. ${ }^{142}$ The bill should also be shown that it conforms with other legal doctrines, principles, the existing law, and international obligations. ${ }^{143}$

To ensure such coherence, other agencies are also consulted, and if criminalization or punishment is included, the Ministry of Justice (Federal Attorney General) would be consulted to make sure that it does not contradict with the Criminal Code. ${ }^{144}$ If the bill has institutional modification implications, the PM Office needs to be consulted before the draft is drawn up. ${ }^{145}$ Finally, before the bill is presented to the Council for discussion, it is presented to the legal team to ensure that it conforms with the policy ${ }^{146}$ and technical requirements. ${ }^{147}$

There are, however, several rules that violate this basic requirement of coherence within the legal system. There are penal rules that contradict the constitutional principle of presumption of innocence ${ }^{148}$ by establishing guilt by presumption or shifting the burden of proof onto the defendant. For instance, the Corruption Crimes Proclamation No 881/2015, article 3 presumes 'intent to obtain an advantage or to injure' and requires the defendant to prove otherwise. Likewise, the crime of 'unexplained property' provided for under article 15 of Suppression and Prevention of Money Laundering and Financing of Terrorism Proclamation No 657/2009 is based on a presumption of guilt. ${ }^{149}$

Article 20(4) of the FDRE Constitution, enshrines two fundamental procedural rights. The first part provides that 'accused persons have the right to full access to any evidence presented against them, [and] to examine witness testifying against them'. Article 23 of the former Anti-Terrorism

${ }^{142}$ CM Working Directive, supra note 33, art 42(5)(a)).

${ }^{143}$ Id., art 46(1).

${ }^{144}$ Id., arts $42(5)(b), 42(1)(c)$.

145 Id., art 42(7).

${ }^{146}$ It is apparent that before a bill is drawn up the Agency needs to have a policy document to be adopted by the Council. It is based on such a policy document the bill would be drawn up. Id., arts 40(5), 45.

${ }^{147}$ A bill presented to the Council should be prepared in Amharic and English languages accompanied by a brief explanatory memorandum. The language must be of a high standard, etc. Id., arts 9(6), 43(2) 45. However, this is also the requirements when the bill is sent to the House.

${ }^{148}$ FDRE Const, art 20(3) provides that 'accused person have the right to be presumed innocent until proved guilty according to law and not to be compelled to testify against themselves'. One may see that there is no exception to this rule.

149 The punishment is 'confiscation' of the unexplained property, 'imprisonment from three to five years and fine from Birr 5,000 to Birr 10,000'. 
Proclamation No 652/2009, provided that 'intelligence report prepared in relation to terrorism, even if the report does not disclose the source or the method it was gathered; [and] hearsay evidence' is admissible. This provision is repealed in the recently adopted Prevention and Suppression of Terrorism Crimes Proclamation No 1176/2020.

The second part of article 20(4) of the Constitution provides that defendants have the right 'to adduce or to have evidence produced in their defence, and to obtain the attendance of and examination of witnesses on their behalf before the court.' In the face of such fundamental rights, article 43(5) of the Criminal Code, provides that for crimes committed through the mass media 'the content of the matter shall be deemed to have been inserted, published or disseminated with [...] full knowledge and consent' of the editor-in-chief, the printer, the author, editor, and publisher. It is further provided that ' $[\mathrm{n}] \mathrm{o}$ proof to the contrary may be admitted in such a case'. ${ }^{150}$

The criminal law is based on four fundamental principles which are also incorporated in the Criminal Code - the principle of legality, the principle of conduct, the principle of guilt and the principle of personal responsibility. ${ }^{151}$ In not a few cases, contrary to the principle of legality, the criminalised conduct is just not clear. For instance, the Suppression of Money Laundering and Financing of Terrorism Proclamation No 675/2009, article 17(5) provides that 'whosoever contravenes any other provisions of this Proclamation shall be punished under the provisions of the Criminal Code.'

Article 58(7) of the Banking Business Proclamation No 592/2009 provides that: "[a]ny person who contravenes or obstructs the provisions of [the] Proclamation or regulations or directives issued to implement [the] Proclamation shall be punished with a fine up to Birr 10,000 and with imprisonment up to three years." And according to art. 78(2) of the Mining Operations Proclamation No 678/2010, "[a]ny person who contravenes or fails to comply with any provision of this Proclamations, regulation[s], directives or the terms and conditions of a license, shall be punished with fines up to birr 200,000 or imprisonment up to five years or both."

${ }^{150}$ What is worse is the said 'crime' may have not been committed by the accused, however, criminal liability is attached to status as 'editor-in-chief', or 'publisher', 'producer', or 'licensee' which are given meaning in Freedom of Mass Media and Access to Information Proclamation No 590/2008 in order to give effect to those provisions of the Criminal Code. 'Explanatory Memorandum on Freedom of the Media', supra note 115, at 12, 14, 28, 29.

${ }^{151}$ For an in-depth discussion on those principles, see Simeneh 'Methods and Manners', supra note 25 . 
These provisions violate the principle of legality in different levels. As a rule of conduct for the individual, the conducts criminalised are vague and cannot be complied with. The conducts are not fully predefined, and embody clauses that envisage regulations and directives yet-to be issued by the Executive which has no criminal lawmaking power. ${ }^{152}$ In some instances, where the violation is against a directive, the criminal norms (the prohibited conducts and/or the punishment) are not published in the official Negarit Gazeta.

Contrary to the principle of conduct, the Income Tax Proclamation No 286/2002, article 102(1), and Value Added Tax Proclamation No 285/2002, article 56(1) provide that if a company is found guilty of tax crimes as defined in the respective proclamations, '.. the manager of that entity at the time of the commission of the offence is treated as having committed the same offence and is liable to a fine and imprisonment' fixed for the company. Those provisions also contradict the principle of guilt.

Finally, the principle of lenity is an important principle of criminal law enshrined both in the Constitution ${ }^{153}$ and the Criminal Code. ${ }^{154}$ The penal provisions in those administrative regulatory legislation are drawn in a consistent manner preferring for a graver penalty. For instance, article 45 of the Broadcasting Services Proclamation No 533/2007, provides for specific jail term punishment and fine to be imposed for persons violating the provisions of the Proclamation '[u]nless punishable with more severe penalty under the Criminal Code' ${ }^{155}$

152 See text for n 37. Further, Forest Development, Conservation and Utilisation Proclamation No 524/2007, art 20(6) of the provides that a person who "commits a fault that are not mentioned in sub-article (1) to (5) here in above and for which punishment is not imposed shall be punishable with not less than 6 months and not exceeding 5 years imprisonment and with fine Birr 30,000'. Likewise, Proc No 980/2016, supra note 51, art 49(8) provides that '[a]ny person who violates the other [sic] provisions of this Proclamation shall be punished with fine from Birr 10,000 (ten thousand) to Birr 30,000 (thirty thousand) and with simple imprisonment from one year to three years.'

153 Art 22 provides for the non-retroactivity of the criminal law and punishment. However, 'a law promulgated after the commission of the offence shall apply if it is advantageous to the accused or convicted person'.

154 Art 5 provides for the non-retroactive application of criminal law. However, art 6 provides that the provisions of the Criminal Code apply to an accused person if "they are more favourable to him than those in force at the time of the commission of the crime'.

155 There are similar provisions in Development, Conservation and Utilisation of Wildlife Proclamation No 541/2007, art 16(1); Forest Development, Conservation 
Therefore, the system of norms is not coherent within itself, and some rules even contradict the basic doctrine of criminal law.

\subsection{The coherence of norms with the reality (external coherence)}

The coherence of the legal system fairly relates to the validity of laws and the coherent co-existence of norms. However, formal validity is not sufficient for the continued existence of norms. Wintgens upholds that formal validity is a reason for the initial existence of a norm; its continued existence is justified by its coherence with reality. ${ }^{156}$ The law must be reasonably complied with by the public and it must be able to be enforced by law enforcement authorities. This is what Oliver-Lalana refers to as 'social rationality' and 'goal rationality'. ${ }^{157}$ The law adopted must be accepted and complied with by society and it must be one that helps achieve its intended goal.

However, certain criminal rules do not cohere with reality, and some are not clear. For instance, the Commercial Registration and Business License Proclamation requires the trader to have a valid (renewed) license to conduct his business. When such a rule is violated, a certain punishment may be imposed. The punishment is, among others, a fine between Birr 150,000 and Birr 300,000. If a person has an initial capital of less than Birr 150,000 which is often the case, and his entire asset is less than Birr 150,000, the punishment cannot be enforced at all. Such law is unrealistic.

The cardinal purpose of the tax law is to maximise state revenue, and there are various ways of obtaining such revenue. Likewise, the Explanatory Memorandum on Commercial Registration and Business License Draft Bill' indicates that the requirement of a license is to maximise state revenue. ${ }^{158}$ The sole justification for excessive punishment in both laws that incorporate penal provisions is to strictly enforce the revenue collection activity. If a person is punished twice for the same purpose (under the tax and registration

and Utilisation Proclamation No 542/2007, art 20; Biosafety Proclamation No 655/2009, art 21; Copyright and Neighbouring Rights Protection Proclamation No 410/2004, art 36(1), (2).

156 See supra note 34.

${ }^{157}$ Oliver-Lalana, supra note 11, at 140-144.

158 'Explanatory Memorandum on Commercial Registration and Business License Draft Bill' (later adopted into law as Proc No 686/2010); Brief Minutes of Public Hearing Organised by the Trade and Industry Affairs Standing Committee on Competition and Consumers' Protection, and Commercial Registration Draft Bills, 23 June 2010 (later adopted into law as Proc Nos 685/2010 and 686/2010, respectively) at 44-45, 61-62. 
laws), each of which, in their own right, is disproportionately severe punishment, it is excessive use of the criminal law.

For instance, all of those who (were alleged to have) engage(d) in trade without a valid (renewed) commercial license were sentenced to a term of imprisonment, some of which are suspended ones, irrespective of their personal predicaments. Yet, the court is not imposing the legally provided amount for punishments. The law determines fine between Birr 150,000 and 300,000 . The court consistently imposes a fine not exceeding Four Thousand Birr. This author has never encountered a case where property confiscation is ordered. On the other hand, after the provision criminalising transfer of commercial license was adopted, 737,930 business license were deactivated in the year 2018 of which 708,306 were in Addis Ababa. ${ }^{159}$ It appears that the law causes more harm than positive outcomes.

\section{The Duty of Deliberation and to Give Reason}

As indicated earlier, the principal duties of the lawmaker are making laws and supervising the executive that its laws are properly implemented. ${ }^{160}$ It is discussed in great length that legislating is normative judgment and it requires good justifications. Such justifications may be developed only through the process of deliberation. ${ }^{161}$ Cognizant of such fact, deliberations are recognised in the rules of legislation. Such deliberation is even proper because there are conflicting interests and a mutually agreeable solution could be achieved by such deliberation and voting. Deliberation is a method of obtaining both formal validity and political legitimacy. ${ }^{162}$ It is so central in the lawmaking process in every democratic society that some even argue against a stronger judicial review based on their faith in the deliberative process. ${ }^{163}$ The deliberation on a bill is one aspect of the process of justifying the norm.

159 'Business license deactivation growing in Ethiopia'

$<$ https://newbusinessethiopia.com/investment/business-license-deactivationgrowing-in-ethiopia/> last accessed 20 July 2019.

160 FDRE Const, art 51(1) provides that '[t]he House of Peoples' Representatives shall have the power of legislation in all matters assigned by this Constitution to the Federal Jurisdiction'. The following provisions provide for specific legislative powers. This is further provided for in Proc No 470/2005, supra note 2, art 4(1).

${ }^{161}$ Oliver-Lalana, supra note 11 , at $136 \mathrm{ff}$.

162 Id., at 138.

${ }^{163}$ One of the reasons Waldron objects to strong judicial review is taking into the role of the lawmaker as a 'large deliberative body' which has the capacity to deal with difficult issues with sufficient safeguards, such as, bicameralism, strong committee 
There are enquiry researches made based on proposals, policy documents, diagnostic studies, explanatory memorandum, expert recommendations, public discussion, etc. Deliberations fall under two general categories subject to a third category of post-legislation continuous evaluation discussed in Section 9. The pre-legislative deliberation is arguably the longest deliberation that helps the bill to get the final shape as it is presented to the House. The legislative deliberation is conducted by the Committees and in the House.

\subsection{Pre-legislative deliberation}

Every agency has the competence to draw up a bill in its area of competence. ${ }^{164}$ To get into the legislative drafting venture, however, such agency needs to have included in the annual legislative program ${ }^{165}$ to be scheduled in the Council of Ministers and to be communicated by the President of the Republic at the first session in a joint session of both Houses. ${ }^{166}$ It is imperative that prior consultations should be conducted and the reports should demonstrate that such consultations with other public agencies, ${ }^{167}$ professional associations ${ }^{168}$ and stakeholders ${ }^{169}$ and members of the public were made. The findings of the discussion would be presented to the Council of Ministers. ${ }^{170}$

Where the Council finds it essential that the subject requires an in-depth study before the matter is tabled in the Council, it may refer the matter to a standing or ad hoc committee. ${ }^{171}$ Once such deliberations are made, 'a Green Paper' (policy discussion paper marked as 'only for discussion') will be

scrutiny, multiple levels of consideration of the issues and debate. Jeremy Waldron

'The Core of the Case against Judicial Review' (2006) 115 Yale LJ 1346, 1361.

${ }^{164}$ CM Working Directive, supra note 33, art 38(1); Proc No 271/2002, supra note 4, art 6(2)(a).

${ }^{165}$ CM Working Directive, supra note 33, art 38(2).

166 Id., art 36(1).

167 The report should indicate that such consultation with the relevant government agencies was conducted and what their view was and whether they express their agreement to the proposal.

${ }^{168}$ CM Working Directive, supra note 33, art 10(2), (3).

${ }^{169}$ Id., arts 5(3), 10(1)(a)

${ }^{170} \mathrm{Id}$., art 9(4).

${ }^{171}$ Id., art 9(11). One such bill was the first Broadcasting Proclamation No 178/1999. The initial draft was discussed by a technical committee composed of Ministry of Information and Culture, Ministry of Transport and Communication and Ministry of Justice. 'Brief Explanatory Memorandum on Draft Bill for the Regulation of Broadcasting Services' (later adopted into law as Proc No 178/1999) at 2-5. 
drawn up by the proposing agency. ${ }^{172}$ 'A White Paper' (a policy document indicating government policy direction) may be drawn up by the proposing agency and needs to be approved by the Prime Minister prior to a discussion by the Council. ${ }^{173}$ The report of the discussion on the Green and White Papers would be presented to the Council for decision ${ }^{174}$ and every effort should be exerted to obtain a proposal on which there is a consensus by every government agency which participated in such consultation. ${ }^{175}$

The Council of Ministers Working Directive requires specific consultations as compulsory. For instance, if the proposal has budgetary and financial implications, the Ministry of Finance and Economic Development should mandatorily be consulted. ${ }^{176}$ Before drawing up a new bill or create a new institution or introduce fundamental changes in the already existing legislation or institutional structure, the Prime Minister has to be consulted. ${ }^{177}$ If the bill relates to a contentious issue or affects the powers and responsibilities of an agency, that agency should be consulted ${ }^{178}$ and such an agency should provide a written confirmation that the consultation was conducted. ${ }^{179}$ If the bill contains penal provisions, consultations should be made with the Ministry of Justice (currently the Federal Attorney General) to determine its propriety and to avoid contradiction with the Penal Code. ${ }^{180}$

Once a policy opinion is accepted, a policy document will be drawn up and discussions will be conducted. The complexity of the bill to be drawn up will be determined. The deliberations will be conducted to develop a guideline for the drafters of the bill. Once the bill is drawn up, it will be submitted to the legal affairs team regarding its presentation to the Council. ${ }^{181}$

The agency proposing the bill submits the draft to the legal affairs team certifying that the bill does not contradict the Constitution, other laws and doctrines, and international obligations or expressly state where those laws and doctrines are implicated. ${ }^{182}$ After making sure that the bill conforms

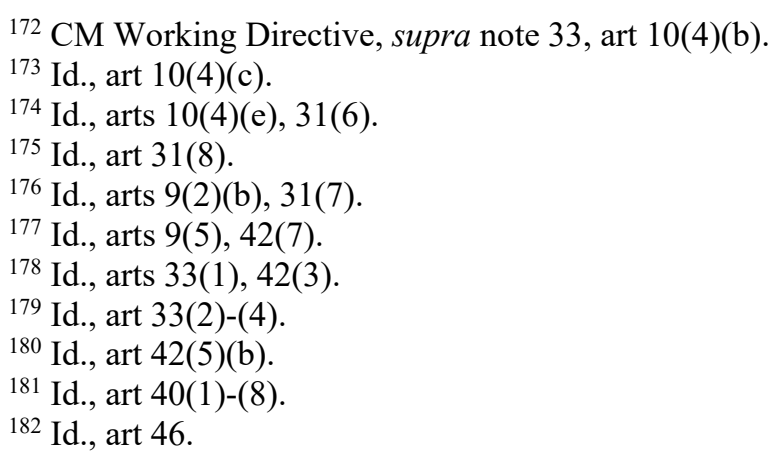


with the policy adopted and meets the technical and quality requirements provided for in article 9, the bill is presented to the Council for a final decision.

The Council may deliberate on the bill or may refer it to the appropriate standing committee after the first reading for further examination and research. ${ }^{183}$ Decisions are to be made after deliberations. The deliberation may be made on line-item, or words and phrases, or in general. ${ }^{184}$ Where the matter is one that requires expertise, the Council may be assisted by experts and resource persons. ${ }^{185}$ At the end of the deliberation, decisions are made by consensus; where consensus is not possible or a member requests for voting, decisions may be made by voting. ${ }^{186}$ The decision may be to adopt the bill, to send it back to the agency for further study, to suspend its hearing for a specific period, or to conduct the debate some other time. ${ }^{187}$

Because the deliberations in the Council of Ministers is classified by such Working Directive, it is not possible to verify the compliance of the procedures with in the process of adoption of a bill before it is sent to the House for adoption into law. However, there are a few observations that may be made. First, policy documents are not being submitted to the House along with the draft bills which gives the impression that the rules of lawmaking are not complied with. Often, bills (drawn up in Amharic and English languages) are submitted to the House only with short explanatory memorandum.

\subsection{Legislative deliberation}

The criminal norms discussed in this article have passed through the prelegislation deliberation in the Council of Ministers with no exception. The bills were submitted to the House for deliberation and adoption into law. There are two phases of deliberation in the House. The bill is presented to the House through the Speaker for first reading. The first reading is 'the reading and discussion process held on a draft bill to be endorsed by the House, before referring it to the pertinent Standing Committee for further

\footnotetext{
${ }^{183}$ Id., art 40(9)-(11).

${ }^{184}$ Id., art 27.

185 Id., arts 13(1), 21.

186 Id., art 28.

${ }^{187}$ Id., art 22.
} 
inspection'. ${ }^{188}$ The first reading is a simple reading of the bill followed by general 'deliberations on the spirit of the draft bill in general'. ${ }^{189}$

Where the House, by a two-thirds majority, decides to see the bill in its regular meeting, the bill would be deliberated on for adoption into law. ${ }^{190}$ But none of the bills discussed here were seen in this manner. All of those bills discussed in this article have passed through the regular process. There was the first reading, presumably, because the records do not show anything; the bill is referred to a Committee or joint Committees. ${ }^{191}$

The Committee(s) conduct a public hearing which is the presentation of the bill to the 'public' by the resource person(s) from the proposing agency. Even though it is not provided for in the law, in a few instances, the Committees conduct 'closed' hearing probably to enhance their awareness about the bill. Thus, the Value-Added Tax bill was initially discussed only in the presence of the Legal Affairs and Economic Affairs Standing Committee members. ${ }^{192}$

The practice of the House regarding a public hearing is that individuals from invited institutions deliberate on the bill. With little or no change to such bill based on such public hearings, the Committee routinely recommends the bill to the House to be adopted into law. In some instances, such as in the case of Anti-Terrorism Proclamation No 652/2009, there was no public hearing at all. ${ }^{193}$

When the bill comes back to the House, there is a second reading. The second reading is 'the discussion on the recommendation and suggestions of the Standing Committee, to which the draft bill was referred for thorough inspection after the first reading'. ${ }^{194}$ At the second reading, the discussion to

${ }^{188}$ Proc No 271/2002, supra note 4, art 2(10).

${ }^{189}$ Id., art 3(9)(c).

${ }^{190} \mathrm{Id} ., \operatorname{art} 3(9)(\mathrm{e})$.

${ }^{191}$ For instance, the Value-Added Tax bill was referred to the Legal and Administrative Affairs, and Economic Affairs Standing Committees jointly. Likewise, the AntiTerrorism Bill was referred to Law, Justice and Administrative Affairs, and Foreign, Defence and Security Standing Committees jointly.

192 See 'Minutes of Meeting on VAT Proclamation', supra note 94; the 'Report and Recommendations from the Budget and Finance Affairs Standing Committee to have the Income Tax Draft Bill Adopted into Law 4 July 2002' (in Amharic) indicates that there had been a public hearing three days earlier on 1 July 2002.

193 There is no record of public hearing. Both the 'Reports and Recommendation on the Anti-Terrorism Draft Bill', supra note 105, and the 'Minutes of Meeting with Stakeholders', supra note 57, rather show the discussion was a closed one.

${ }^{194}$ Proc No 271/2002, supra note 4, art 2(11). This is not the law in force currently. However, specific reference is made to this provision because the bulk of the 
be had is on the recommendations made'. ${ }^{195}$ The House votes on the bill without delving into the content of the bill for deliberation, and it evaluates only the recommendations and suggestions by the Committee.

More or less, the same provisions are contained in Proclamation No 470/2005. However, article 4 of Regulations No 6/2015, ${ }^{196}$ gives a different impression. Article 4(1) provides that 'the draft law shall be deliberated upon in detail.' However, sub-article (2) states that 'the report and recommendation on the draft law prepared by the committee or committees concerned shall be caused to be read to the House.' Sub-article (3) further provides that the deliberation shall be made 'in detail based on the report and the recommendations.' These provisions are equivocal in that, on the one hand, they appear to provide for detailed deliberations on the provisions of the bills; on the other hand, they give the impression that the deliberations, as they are based on the reports and recommendations, are limited to such reports and recommendations.

There are various legislation containing penal provisions adopted both after the adoption of the legislation rules in 2005 and the adoption of the legislative regulations in 2015. The practice continued in the same manner. ${ }^{197}$ Therefore, the equivocation could be interpreted as conformity with the established deliberation practice of the House. This deliberation should reflect the democratic nature of the process and every member, who has a view on the content of the bill, should be heard.

\section{Post-Legislation Evaluation, Revision and Review of Constitutionality}

So far, it is discussed how a bill may be adopted into law following certain standardised procedures. It is stated that the law is prospective and the information used is both established as well as predicted. As time goes by, facts change as they always do by themselves as well as because of the bill

legislation containing penal provisions were adopted after 2002 but before 2005 legislation. However, even after the legislation rule was replaced in 2005, the practice is not changed at all.

195 Proc No 271/2002, supra note 4, art 4(11)(b).

196 Proc No 470/2005, art 39 authorizes the House to adopted regulations. However, Regulations No 6/2015, supra note 43, claims to be adopted as per the provisions of the FDRE Const, art 59(2).

${ }^{197}$ Both the Anti-Terrorism Proclamation and Proc No 980/2016, supra note 51, were adopted after 2005 as per the new legislation rules; however, the same practice continued. 
adopted into law. It is also stated that a norm remains valid if it continues conforming to the social reality. ${ }^{198}$ To ensure that a norm continues conforming to social reality, each norm is evaluated continuously. ${ }^{199}$ If such a norm is in want of revision, it would possibly be the investigation stage of the next bill. However, to justify the revision of a criminal norm, its application must be seen in various forms, one of which is some criminal statistics.

There are several penal provisions revised over the years both expanding criminalisation and increasing sentence. For instance, when the tax laws containing severe penal provisions were adopted, there was already the Penal Code punishing certain conducts relating to tax. There was no data presented in support of the penal provisions of the tax laws. Likewise, when the Commercial Registration and Business License Proclamation was revised repeatedly expanding its scope, there was no criminal statistics presented as a justification. In simple terms, there was no any background research in support of those legislative actions.

One might argue, if the House is not debating the bills, it cannot demand evidence of the social reality and it does not have the quality control mechanism at its disposal. In the fact-finding stage, it was asserted that those laws adopted without proper investigation, or those rules which turn out to contradict reality should have been revised soon after their adoption. For instance, the tax statutes included unjustified criminalisation of conduct, such as strict liability and imputation of criminal liability.

Often, it is to avoid the threat of such 'unjustified criminal responsibility' that individuals obtain a business license and commercial registration through another person. For instance, the coffee export audit report shows that several of those coffee exporters were doing business under a commercial license obtained through another person who is not financially able to undertake such business. ${ }^{200}$ The lawmaker addressed the issue differently -it criminalised transferring one's commercial license to someone else, which entails severe imprisonment. Even though there is no evidence regarding the causal connection, the number of commercial registration that were returned to the Ministry of Trade increased dramatically. ${ }^{201}$

\footnotetext{
${ }^{198}$ Wintgens 'Bounded Rationality', supra note 1, at 3, 5-13.

199 Alberto Muñoz Arenas, 'Theoretical and Procedural Aspects of the Evaluation of Public Policies' in Adan Nieto Martin and Marta Muñoz de Morales Romero (eds) Towards a Rational Legislative Evaluation in Criminal Law, (Springer 2016).

200 'The Ethiopian Coffee and Tea Development Marketing Authority 2001 EC to 2007 EC Coffee Purchase and Export Audit (February 2017)'.

${ }^{201}$ See supra note 159.
} 
Those who argue against 'strong judicial review' principally base their arguments on the democratic nature of lawmaking and the various forms of institutional and normative guarantees. ${ }^{202}$ Taking Oliver-Lalana's five levels of justification, linguistic rationality relates to the principle of legality which can be addressed by a criminal court. Legal rationality, relating to hierarchy of norms along with value rationality could have been handled by the same court, but this power is said to be reserved for the House of Federation $(\mathrm{HoF})$ and Council of Constitutional Inquiry (CCI) in the case of Ethiopia. ${ }^{203}$

A clear case of legisprudential aspect of constitutional review is social rationality (partly coherence with the reality) and goal rationality. Such legisprudential judicial review is almost 'non-existent' in Ethiopia. ${ }^{204} \mathrm{In}$ an ideal situation, constitutional review is not only maintaining a normative hierarchy, but also having a rationally made law; that is, whether the norms adopted by the lawmaker are well justified. In this sense, constitutionality review enquires into whether the lawmaker made the necessary effort to adopt 'good law' by complying with a pre-legislative enquiry into the facts and making prior evaluation of those findings at the legislation stage. ${ }^{205}$ If a rule is justified, there would only be deference to the decision of the lawmaker. ${ }^{206}$

If the $\mathrm{HoF}$ or $\mathrm{CCI}$ believes that the lawmaker does not have obligation to give a reason for the adoption of particular legislation, the lack of justification or poor justification may not be ground for striking out the rule. ${ }^{207}$ However, such legislation is suspect for 'arbitrariness' ${ }^{208}$ This is

202 Strong judicial review as identified by Waldron is 'courts hav[ing] the authority to decline to apply a statute in a particular case [...] or to modify the effect of a statute to make its application conform with individual rights.' Waldron 'Against Judicial Review', supra note 163, at 1354.

${ }^{203}$ Assefa asserts that such power was not given to the courts because there was no trust in the courts of independence and impartiality. Assefa Fiseha 'Constitutional Adjudication in Ethiopia: Exploring the Experience of the House of Federation (HOF)' (2007) in 1 Mizan LR 1, 11.

204 The House of Federation and the Council of Constitutional Inquiry are constitutionally vested with the power to interpret the Constitution. In their more than two decades' life of constitutional interpretation, in the face of patently unconstitutional penal legislation, their presence could not even be felt positively impacting individual rights.

${ }^{205}$ Wintgens 'Bounded Rationality', supra note 1.

206 Oliver-Lalana, supra note 11, at 177-178.

207 This would take us to the theory of legislation which is beyond the scope of this study. 
particularly so in criminal matters because such rules implicate individual fundamental rights. ${ }^{209}$ This should not give the impression that the review is limited to mere meta-procedural review of legislation; nor does the CCI review the justifications de novo for that would be tantamount making policy decisions by the CCI on behalf of the lawmaker; it is rather a mid-way between the two. ${ }^{210}$ Thus, where the CCI finds the norm unconstitutional either because of the natural change of facts because the legislature failed to make rules up to date, the court would have to give the legislature time to make the necessary enquiry and take the appropriate measure. ${ }^{211}$

\section{Conclusion}

The legislative process is one mechanism for ensuring the 'good' content of the law. There are various doctrines -both within the criminal and constitutional laws- that limit the criminal lawmaking power of the state. The obligation to make laws also carries the obligation to make 'good laws'. Even though it is difficult to establish the content of 'good law', it is possible to make agreeable law following a fair procedure.

In exercising its authority, the lawmaker, enquires into the facts with regard to where social interactions have failed, whether they require legislative intervention and whether the criminal law is a necessary measure. In making such a decision, it has to conduct a hearing of different sorts. Apart from complying with the lawmaking process which is intended to be fair, the lawmaker should also adopt rules which cohere among themselves and with reality. As laws are made to be applied prospectively, and as facts change over time, the limited information the lawmaker has certainly affects the quality of legislation; and thus, continuous evaluation is essential. However, these processes have gaps in the context of Ethiopia's criminal lawmaking, thereby necessitating utmost attention at pre-legislation and legislation phases.

\footnotetext{
${ }^{208}$ Oliver-Lalana, supra note 11, at 179.

${ }^{209}$ When two public policy decisions conflict, the lawmaker has to assess and make a determination of which one should be given priority. Where a fundamental right is implicated, the decision is made based on the principle of proportionality.

${ }^{210}$ Wintgens 'Bounded Rationality', supra note 1, at 27.

${ }^{211}$ Id., at 26-27.
} 